\title{
The preventional analysis of tuberculosis under the mechanism of physical healthness in universities
}

\author{
Xiaoqing Dong \\ Henan College of Finance and Taxation, Henan Province, China
}

\begin{abstract}
Tuberculosis is an old chronic infectious disease, which is still a major public health problem threatening people's health. Colleges and universities are the collective places where the students are studying and living. The heavy academic workload, employment pressure and other factors lead to worse health condition, making university students become the high-risk group. From the perspective of physical education, this paper will analyse the reasons why tuberculosis becomes popular in the group of sampled university students in order to establish the self operation mechanism of physical healthness on the platform of universities. In the course of preventing tuberculosis, giving full play to the function of physical education as a medium could be practical significance for adhering to the "people-oriented" concept of scientific development, and constructing a harmonious society.

Index Terms - college and universities, tuberculosis, influcing factors, precention, physical education
\end{abstract}

China is the country with a high incidence of tuberculosis, and tuberculosis prevalence ranks second in the world, only after India. China is also listed as one of the 22 tuberculosis high-burden countries [1]. In 2009,"World Tuberculosis Day" campaign launched. The Ministry of health has been focusing on tuberculosis control of rural population and the floating population. Colleges and universities are the collective learning and living places for students, where population mobility is large, and all the factors interact. With the expandation and combination of many colleges and universities, the school's population density is relatively increased. Plus the heavy academic workload, employment pressure and other factors lead students to the worse health condition and instable immune function. Therefore, the students in colleges and universities become the high-risk population to tuberculosis. In recent years, the morbidity rate of tuberculosis and other infectious diseases is generally higher. If the source of tuberculosis infection is not control properly, it is extremely easy to cause its outbreaks. Finally, it will seriously affect students' normal study life and health condition. Therefore, from the actual situation, taking effective measures can make the prevention work on the track of better development. All these measures are significant to keep down the incidence and prevalence of tuberculosis effectively, which ensure the students have a better health condition, learning and living environment, and stabilize school teaching orders.

The paper investigates and analyses the epidemiologic situation and relative cause of tuberculosis in Henan Province. The questionnaire objects are 126 college students who were diagnosed TB patients by Zhengzhou city hospitals and prevention and control institutions from January 2009 to December 2011 as the case group. Besides that, another 154 are chosen at random as a control group from some certain universities where tuberculosis was found in their students. Based on the "Guidelines on the prevention of Chinese TB control planning and Implementation", the entire control group has not history of tuberculosis, and there are no symptoms of respiratory infection in three weeks. Questionnaires were issued 280 copies, 280 were recovered, and the recovery rate is $100 \%$. All the returned questionnaires have been analysed and examined by the logic analysis. Valid questionnaires are 246 copies, and effective rate was $87.08 \%$.

\section{The cause and route of infection of pulmonary tuberculosis}

\section{A. The pathogenesis of primary pulmonary tuberculosis}

When the human resistance is lowered, tuberculosis can be infected into the human body through the respiratory or digestive tracts, forming primary foci in the lungs or intestinal walls. It is about $90 \%-95 \%$ occurrence of pulmonary tuberculosis in the lungs. Infected tuberculosis can be breathed through respiratory tract, windpipe, bronchial tubes and finally into alveolus. As a results, exudative inflammatory lesion can be caused in any area of lungs, which is called primary lesions ${ }^{[2]}$.

\section{B. Causes of hematogenous disseminated pulmonary tuberculosis}

When the human resistance is lowed, a lot of tuberculosis at a time or in a very short time may invade blood circulation many times. This can cause the hematogenous disseminated pulmonary tuberculosis. At this time, due to the increased body allergy, it can enhance vascular permeability. Tuberculosis can be invaded into pulmonary interstitial through the vessel wall invasive, forming nodule after invasion of lung parenchyma ${ }^{[2]}$.

\section{Route of infection}

Tuberculosis is spread mainly through the respiratory tract. The main source of infection is the discharge of sputum contained bacteria of pulmonary tuberculosis. The minor route of infection is through the body through the digestive tract.

\section{Analysis of the causes of tuberculosis epidemic factors}

A. The influencing factors of tuberculosis and evaluation (see the TABLE I)

The findings from the table I reveal 10 influencing factors of tuberculosis (studying pressures, living environment, BMI, family economic conditions, physical exercises, diet habits, sleeping hours, daily on-line hours, the past history of 
respiratory tract, knowledge of tuberculosis prevention) and their evaluations.

TABLE I The influencing factors and Evaluation

\begin{tabular}{|c|c|}
\hline Influencing factors Evaluation & Influencing factors Evaluation \\
\hline $\begin{array}{l}\text { No, } X=0 \\
\text { Yes, } X=1\end{array}$ & $\begin{array}{l}\text { Diet habits having a breakfast, } \\
X=0 ; \\
\text { No breakfast, } X=1\end{array}$ \\
\hline $\begin{array}{l}\text { Living environment } \\
\text { The number of quarters } \leq 4, X=0 \text {; } \\
\text { The number of quarters }>4, X=1\end{array}$ & $\begin{aligned} \text { Sleeping hours } & <8 \mathrm{~h}, \mathrm{X}=0 \\
& \geq 8 \mathrm{~h}, \mathrm{X}=1\end{aligned}$ \\
\hline $\begin{array}{r}\mathrm{BMI}=\text { weight }(\mathrm{kg}) /[\text { hight }(\mathrm{m})]^{2} \\
\mathrm{BMI}<18.5, \mathrm{X}=0 ; \\
5 \leq \mathrm{BMI}<24, \mathrm{X}=1 ; \\
\mathrm{BMI} \geq 24, \mathrm{X}=2\end{array}$ & $\begin{aligned} \text { Daily on-line hours } & \geq 4 \mathrm{~h}, \mathrm{X}=0 ; \\
& <4 \mathrm{~h}, \mathrm{X}=1\end{aligned}$ \\
\hline $\begin{array}{l}\text { Family economic conditions } \\
\qquad \begin{array}{l}\text { Normal, } \mathrm{X}=0, \\
\text { Better, } \mathrm{X}=1\end{array}\end{array}$ & $\begin{array}{l}\text { The past history of respiratory } \\
\text { tract } \\
\text { No, } X=0 ; \\
\text { Yes, } X=1\end{array}$ \\
\hline $\begin{array}{l}\text { Physical exercise } \\
\qquad \begin{array}{l}3 \text { times a week, } X=0 ; \\
\text { Times of a week }<3, X=1\end{array}\end{array}$ & $\begin{array}{lcr}\begin{array}{l}\text { Knowledge } \\
\text { prevention }\end{array} & \text { of } \quad \text { tuberculosis } \\
& \text { Known, } X=0 ; \\
& \text { Not known, } X=1 \\
\end{array}$ \\
\hline
\end{tabular}

B. The tuberculosis single factor analysis of influencing factor of results in college students of Henan Province (see TABLE II)

The findings from the table II show that there is a relationship among BMI, physical exercises, diet habits, hours of sleep, daily on-line hours, TB prevention knowledge and pulmonary tuberculosis with statistical significance $(\mathrm{P}<0.05)$, but there is no statistical meanings between other influencing factors and pulmonary tuberculosis $(\mathrm{P}>0.05)$.

TABLE II The tuberculosis single factor analysis of influencing factor

\begin{tabular}{|c|c|c|c|c|c|c|c|}
\hline $\begin{array}{l}\text { Influencing } \\
\text { factors }\end{array}$ & $\begin{array}{l}\text { evalu } \\
\text { ation }\end{array}$ & $\begin{array}{l}\text { Cases } \\
\text { (person) }\end{array}$ & $\begin{array}{l}\text { The } \\
\text { control } \\
\text { number } \\
\text { (person) }\end{array}$ & $\mathrm{X}^{2}$ & $P$ & OR & $\begin{array}{c}\text { OR95\% } \\
\text { CI }\end{array}$ \\
\hline $\begin{array}{l}\begin{array}{l}\text { Studying } \\
\text { pressures }\end{array} \\
\end{array}$ & \begin{tabular}{|l|}
0 \\
1 \\
\end{tabular} & $\begin{array}{l}115 \\
11 \\
\end{array}$ & $\begin{array}{l}141 \\
13 \\
\end{array}$ & 0.007 & 0.932 & 1.037 & $\begin{array}{l}0.448 \\
\sim 2.402 \\
\end{array}$ \\
\hline $\begin{array}{l}\text { Living } \\
\text { environment }\end{array}$ & \begin{tabular}{|l|}
0 \\
1 \\
\end{tabular} & $\begin{array}{l}7 \\
119 \\
\end{array}$ & $\begin{array}{l}12 \\
142 \\
\end{array}$ & 0.548 & 0.459 & 1.437 & $\begin{array}{l}0.548 \\
\sim 3.766 \\
\end{array}$ \\
\hline BMI & \begin{tabular}{|l|}
0 \\
1 \\
\end{tabular} & $\begin{array}{l}63 \\
34 \\
\end{array}$ & $\begin{array}{l}37 \\
68 \\
\end{array}$ & 20.628 & 0.000 & 3.162 & $\begin{array}{l}1.901 \\
\sim 5.275 \\
\end{array}$ \\
\hline $\begin{array}{l}\text { Family } \\
\text { economic } \\
\text { condition } \\
\end{array}$ & $\begin{array}{l}0 \\
1\end{array}$ & $\begin{array}{l}51 \\
75\end{array}$ & $\begin{array}{l}58 \\
96\end{array}$ & 0.231 & 0.631 & 0.888 & $\begin{array}{l}0.548 \\
\sim 1.439\end{array}$ \\
\hline $\begin{array}{l}\text { Physical } \\
\text { exercise }\end{array}$ & $\begin{array}{l}0 \\
1\end{array}$ & $\begin{array}{l}59 \\
67\end{array}$ & $\begin{array}{l}36 \\
118\end{array}$ & 16.998 & 0.000 & 0.346 & $\begin{array}{l}0.207 \\
\sim 0.577\end{array}$ \\
\hline Diet habits & $\begin{array}{l}0 \\
1\end{array}$ & $\begin{array}{l}38 \\
88\end{array}$ & $\begin{array}{l}19 \\
115\end{array}$ & 13.575 & 0.000 & 0.326 & $\begin{array}{l}0.177 \\
\sim 0.602\end{array}$ \\
\hline $\begin{array}{l}\text { Sleeping } \\
\text { hours }\end{array}$ & $\begin{array}{l}0 \\
1\end{array}$ & $\begin{array}{l}30 \\
96\end{array}$ & $\begin{array}{l}15 \\
139\end{array}$ & 10.170 & 0.001 & 2.896 & $\begin{array}{l}1.958 \\
\sim 5.671\end{array}$ \\
\hline $\begin{array}{l}\text { Daily on- } \\
\text { line hours }\end{array}$ & $\begin{array}{l}0 \\
1\end{array}$ & $\begin{array}{l}44 \\
82\end{array}$ & $\begin{array}{l}97 \\
57\end{array}$ & 21.837 & 0.000 & 3.171 & $\begin{array}{l}1.940 \\
\sim 5.181\end{array}$ \\
\hline $\begin{array}{l}\text { The past } \\
\text { history of } \\
\text { respiratory } \\
\text { tract }\end{array}$ & $\begin{array}{l}0 \\
1\end{array}$ & $\begin{array}{l}115 \\
11\end{array}$ & $\begin{array}{l}147 \\
7\end{array}$ & 2.017 & 0.155 & 2.009 & $\begin{array}{l}0.755 \\
\sim 5.345\end{array}$ \\
\hline $\begin{array}{l}\text { Knowledge } \\
\text { of } \\
\text { tuberculosis } \\
\text { prevention }\end{array}$ & $\begin{array}{l}0 \\
1\end{array}$ & $\begin{array}{l}95 \\
31\end{array}$ & $\begin{array}{l}140 \\
14\end{array}$ & 12.363 & 0.000 & 3.286 & $\begin{array}{l}1.660 \\
\sim 6.504\end{array}$ \\
\hline
\end{tabular}

C. The multivariate analysis of influencing factors of pulmonary tuberculosis in college students of Henan Province

Referring to all analysis results on influencing factors, BMI, physical exercise, diet, sleep, daily online time, TB prevention knowledge 6 variables have been done a multivariate non conditional Logistic regression analysis. The results show that 6 variables and pulmonary tuberculosis associated with statistically significant differences $(\mathrm{P}<0.05)$. (See TABLE III)

TABLE III The multivariate analysis of influencing factors of pulmonary tuberculosis

\begin{tabular}{|l|c|c|c|c|c|}
\hline Influencing factors & $\mathrm{B}$ & $\mathrm{SE}$ & $\mathrm{WaldX}^{2}$ & $\mathrm{P}$ & $\mathrm{CR}$ \\
\hline BMI & 0.247 & 0.141 & 4.065 & 0.038 & 3.230 \\
\hline Physical exercise & -0.702 & 0.284 & 6.133 & 0.013 & 0.495 \\
\hline Diet habits & -0.365 & 0.123 & 8.845 & 0.003 & 0.340 \\
\hline Sleeping hours & 1.142 & 0.413 & 7.632 & 0.006 & 2.817 \\
\hline Daily on-ine hours & 0.845 & 0.271 & 9.763 & 0.002 & 2.329 \\
\hline $\begin{array}{l}\text { Knowledge of tuberculosis } \\
\text { prevention }\end{array}$ & 0.869 & 0.236 & 13.515 & 0.000 & 2.384 \\
\hline
\end{tabular}

In addition to the above factors, it is found that, in students of pulmonary tuberculosis patients' interview, individual patients have been in a short time contacted with TB patients. Moreover, the individual patient has not paid attention to ventilation in the activity and living environments. All these results show that transmission of tuberculosis mainly is through the air, and droplet path formed respiratory epidemic. The main sources of infection are the patients of pulmonary tuberculosis with sputum, and the main route of transmission is respiratory tract. Generally people are easily infected, and even in the public places where there are lots of people, such ad colleges and universities. The analysis on the causes of tuberculosis epidemic is mainly because the students are in the growth stage when the immune function is not stable, diet habit, sleep time can not be guaranteed, and they lack of physical exercise, resulting in poor physical condition. Plus that, a poor air circulation in Internet cafes and TB prevention knowledge deficiency finally cause the spread of tuberculosis.

\section{Tuberculosis prevention strategies for college students}

\section{A. Do health check, timely detect tuberculosis pathogen}

Health check is an important method to find patients. Health check is organised by the colleges and universities every year, and it is a chance for TB screening, such as the annual physical examination for university freshmen, the graduates and so on. The first check is the chest X-ray for all subjects, and suspicious cases must obtain a chest film. In this way, it can timely detect tuberculosis patients among students. According to the statistics, the number of new cases found in this way every year is about $1 \%$. Furthermore, timely and early detection of new cases is the key for prevention and treatment of tuberculosis. 


\section{B. Strengthen leadership, increase the propaganda, standardized management}

Preventing and treating pulmonary tuberculosis is inseparable from the joint efforts of the whole society and the government. It is significant to mobilize all the staff and students, producing internal propaganda among students, so that everyone has the common knowledge about tuberculosis and the seriousness of TB health hazard. The environment in the campus must be strengthen, paying attention to indoor ventilation, stopping spitting, promoting campus culture, improving the cultural quality of the whole nation.

The university hospital should be closely linked with the provincial, city, District Health Bureau, Centres for Disease Control and Tuberculosis prevention and control institutions. They all together as a whole form network, and resolutely take effective isolation measures on the new cases restricted to designated hospital for treatment, where chemotherapy is standardized, scientific.

\section{The measures are effective, clear responsibility, fulfil reach the designated position}

To carry out health education for freshmen each year in the college and universities, the groups of PPD test negative as a key object of monitoring. ${ }^{[3]}$ In order to raise the targeted groups' cognition of tuberculosis prevention and control, change their obsolete wrong idea, the use of various forms could be made to educate students, such as presentation on health, elective course. Strengthening the university teachers and students to understand prevention and control knowledge education of tuberculosis and other infectious diseases, selfprotection awareness and ability are significant important.

The floating population working or studying in the campus should be required to do a general health examination, especially having a chest X-ray or chest X-ray examination. Once found the patient must be immediately sent to local treatment. If suspects have cough, expectoration for 2 or 3 weeks, fatigue, fever and other symbols, it must be reported to the certain department in charge for hospital screening. Timely grasping the epidemic dynamics, establishing perfectly all kinds of control system, taking practical measures and supervise the implementation ensure that the control work effectively. When there are pulmonary tuberculosis epidemic or outbreak signs, it must be reported to the hospital and the school leadership. It is also necessary to start up immediately infectious disease prevention plans, take effective control measures, in order to extinguish the epidemic in the bud.

\section{Extracurricular physical exercise under administrative intervention}

Not all infected people do have tuberculosis. Many studies have shown that the incidence of tuberculosis is only $5 \%-10 \%$ among the infected people. Whether or not be attacked by tuberculosis depends mainly on the following three conditions: (1)The virulence of Mycobacterium tuberculosis: virulence of different district tuberculosis is not completely same, which is generally divided into strong, medium and weak. According to the researches, most of TB in China is strong virulence. (2)The amount of TB bacteria: early infection incidence and invasion of bacteria is related to the amount of TB bacteria in human body. Being close with the TB patients is higher risk to be infected. (3)Immunity: immune refers to human resistance to bacteria and virus force. Whether not to be attacked by mycobacterium tuberculosis in human body depends on the human resistance. If the body is strong, resistance is strong, which means that human resistance can resist various pathogens to enter. Otherwise, if the volume of Mycobacterium tuberculosis virulent bacteria is large and immune function is low, people can be attacked susceptibly by tuberculosis.

It is found that, in the analysis of tuberculosis epidemic cause investigation, relationship between physical exercise and tuberculosis has a statistical significance. Physical exercise can strengthen physique, enhance the human body's resistance. Therefore, colleges and universities should pay attention to strengthening students' physical training.

In the present college physical education teaching, classroom teaching is the most main. Currently there is 90 mins physical education (PE) a week, which means that the hours of doing physical exercises is limited. Therefore, the view of only relying on physical education to enhance the physique is difficult to be supported. According to the curriculum theory, sports activities and sports competition is an extension of the physical education teaching in colleges and universities, and it is the most effective means of strengthening the body. The extracurricular physical training is a kind of spirit "regulator", and it is an optimal method to excite, eliminate students' brain fatigue caused by daily studying and mental stress. Therefore, we should give full play to the special function of extracurricular sports activities system. Students' self consciousness of doing physical exercise can be cultivated by many channels. The extracurricular activities have been seen as an important index to evaluate a student, in order to promote the formation of students' physical exercise consciousness.

\section{a) The specific implementation of extra-curricular physical exercise}

The establishment of extracurricular sports management system must be Strengthen. Under the unified leadership in the colleges and universities, "three lines" management mode should be established.

(1) Teachers in department of physical education have the functions of commanding, advising and guiding; department of physical education should actively organize the academy level of major sports events focusing on the enhancement of students' physical quality and enriching students' after-class life. In addition to regular football, basketball, volleyball, football and other ball games, department of physical education should organize more interesting sport activities to mobilize the enthusiasm of the students. They also must seriously implement the national physical training standards in order to improve the compliance rate of physical activity and enhance the students' physical quality. Through a variety of forms of propaganda, students' understanding of the importance of sport will be enhanced. 
(2) The student sports association, sub-sports association, individual sports associations, exerting the functions to be students' own master.

The organization and management of College Students' sports associations and other organizations are running by students themselves. All these associations are the indispensable part of school management system as an "assistant", and they are an important platform for college students to participate in extracurricular activities. In sports, students can enhance the resistance and trust so that improve their interpersonal relationship, cultivate students' decisive independent ability and perseverance, enhance physical fitness. Besides that, sub-sport associations should assist the sport association well and report work. The sport association can timely grasp the progress of all the work of the subassociation in order to provide a good external sports environment for the college students.

(3) School, Department, class and dormitory organise and participate in the work

The college sports committees of each department are responsible for the specific work of sports. Various work regarding to physical education has plans and is included in the Department's work plan, equipped with full-time or parttime teachers, sports funds. Establishing management system of extracurricular sports management system and extracurricular sports activities network ensure the quality of activities and good supervision of the Department of in all kinds of activities.

Follow the guidance of school, the department set sports activities. Under the leadership of the class committee, the class organizes the sports activities, such as skipping rope, tug of war. In the internal of dormitory, dormitory can also carry out sports competitions, the same as in the class, paying attention to the qualities of interest, seasonal, complementary.

\section{E. Using the theoretical course of physical education into the health education development}

Physical education as a public basic course, has its special functions. The health education knowledge must be imparted to students in the form of theory, which has become a major bright spot of physical education. Every year, health education lectures are always carried out for the new entrance as the first priority. Thus, imparting knowledge to students of tuberculosis prevention and treatment of $\mathrm{TB}$ is popular effective method in the form of lectures with some vivid videos. It actively and effectively promote the prevention and treatment of pulmonary tuberculosis, in order to raise the students' awareness of the prevention of infectious diseases, to develop good health habits, to a very good role in promoting to improve students' health literacy plays. In recent years, many tuberculosis researches from colleges and universities show that preventive treatment can reduce the incidence rate of $88.62 \%$. But, along with the increase of people living standard in China, the high risk population of preventive treatment is feasible.

In addition, students are easy to accept the new knowledge. They also can disseminate scientific information and influence people's views and behaviours. The propaganda of basic knowledge about $\mathrm{TB}$ to the parents and the community can let the local resident know the knowledge of tuberculosis prevention and control. Therefore, TB health promotion activities in the school not only can effectively prevent the occurrence of tuberculosis of young students, but also to the whole society play an important role in the prevention of tuberculosis control work.

\section{Conclusion and suggestions}

The main source of pulmonary tuberculosis is the infected patients with sputum. The main route of transmission is in the respiratory tract, and tuberculosis is easily outbreaken in schools and other public places ${ }^{[5]}$. Furthermore, the students are in the growth stage when the immune function is not stable, diet habit, sleep time can not be guaranteed, and they lack of physical exercise, resulting in poor physical condition. Plus that, a poor air circulation in Internet cafes and TB prevention knowledge deficiency finally cause the spread of tuberculosis. Enhancing body's resistance is the most important in preventing pulmonary tuberculosis. Doing regular physical examination can have the early detection and early treatment. The leaders need pay attention to the prevention, establish and perfect the prevention system. Implementing strict responsibility system, a class adviser is first person to report University Hospital students' incidence of tuberculosis. Colleges and universities should increase funding into sports, with administrative intervention methods to help students to strengthen physical exercise, enhanced physique, resist the tuberculosis infectious disease invasion. The propaganda of health education must be carried out to improve students' awareness on TB, encourage students to develop good health habits.

\section{References}

[1] D. Xiao, et al, Working guide for the implementation of tuberculosis control program. Beijing: Peking Union Medical College press. 2008:1.

[2] Y. Yang, N. Cai. Difficulties and Countermeasures of tuberculosis prevention and control work in Institutions of higher learning. Chinese Medical. 2005, 2 (19), 103.

[3] F, Wang, Epidemiological survey of tuberculosis among university students, The utility of Preventive Medicine. 2004.12. 